\title{
FEATURES OF THE FORMATION OF THE MUSICAL COMPREHENSION OF SENIOR SCHOOLCHILDREN
}

\author{
Leyla Ruslanovna Konurova \\ Teacher Department of "Music Education", Gulistan State University \\ Zokir Djurakulovich Khomidov \\ Senior Teacher, Department of "Music Education", Gulistan State University
}

\section{ABSTRACT}

The article discusses topical issues of educating the artistic comprehension of senior schoolchildren by means of musical art. The processes of its formation are considered, which includes the goal, objectives, content of music education, psychological and pedagogical conditions, means, organizational forms and methods; the peculiarities of the studied process in the music lesson, the pedagogical potential of the complex application of various types of musical activity of students is revealed.

KEYWORDS:- Musical comprehension, music lessons, students, formation, complexity, methods, methods of musical education, musical and aesthetic environment, activation, types of musical activity.

\section{INTRODUCTION}

According to the Resolution of the President of the Republic of Uzbekistan "On measures to raise the system of spiritual, moral and physically harmonious education of young people, their training and upbringing" PD-3907 dated August 14,2018 to a qualitatively new level, “... our country is consistently implementing measures aimed on the formation of a harmoniously developed generation, upbringing of spirituallymoral and physically healthy youth, turning it into an active participant in ongoing reforms" $[1]$.

In the Resolution of the President of the Republic of Uzbekistan

"On the organization of the activities of the Union of Composers and Compositions of Uzbekistan" PD-3212 of 15.08.2017; it says that “... At present, in raising the cultural level of our people, educating our compatriots, especially the young generation, in the spirit of high humanistic ideas, love and devotion to the Motherland on the basis of national and universal values, the role and significance of musical art is unlimited" [2].

Currently, the general education school and, of course, music lessons, aimed at shaping the musical culture of students, play a decisive role in shaping the musical comprehension of the 
CURRENT RESEARCH JOURNAL OF PEDAGOGICS 2(5): 78-83, May 2021

DOI: https://doi.org/10.37547/pedagogics-crjp-02-05-15

ISSN 2767-3278

(C)2021 Master Journals

\section{Crossref dof 81 Google}

Accepted 25 $5^{\text {th }}$ May, 2021 \& Published 31 ${ }^{\text {th }}$ May, 2021

younger generation.

At the lessons of musical culture, students acquire knowledge, skills and abilities in musical literacy, music history, vocal and choral work, which create a colossal basis for further musical self-education and artistic self-education, which are the basis for the subsequent cognitive-value attitude of the individual to music, which will be able to understand and enjoy music all your life. It is well known that only a school can help the younger generation to be creatively realized, expand communicative ties, develop educational interests and create value orientations.

\section{THE MAIN FINDINGS AND RESULTS}

Comprehensionis an integral component of the general culture of a person, which determines his artistic, aesthetic and intellectual development, forms his ethical and aesthetic values.

Perception and understanding of works of classical music requires some preparation, listening experience, knowledge.

Indiscriminate consumption of musical information, lack of musical and auditory experience negatively affects the emotional and behavioral manifestations of people.

The tendency to consider music as a means of entertainment for most people has always existed, as pointed out by T.V. Adorno [3].

Mass comprehension is formed in popular culture, often limited and indiscriminate. The commercialization of musical art forms a type of undemanding, limited in their preferences listener, able to perceive only light, unpretentious songs and melodies, which leads to a decrease in the general musical culture and negatively affects the formation of musical comprehension in the younger generation.

Currently, the definition of the concept of "musical comprehension" is considered a controversial and complex problem, which still does not have an unambiguous solution.

So, O. I. Strikhar understands the ability of people to differentiate, but adequately respond to various manifestations of musical art, in its inextricable connection with the surrounding reality through the following factors, by musicalaesthetic comprehension: sensory (emotions, feelings and experiences), axiological (intuitive guesses, aesthetic assessments) and priority (advantages and needs) [13, pp. 423-425].

From the point of view of I.V. Efremova, musical comprehension is regarded as "a kind of artistic and aesthetic comprehension and is considered as a cognitive-value attitude of a person to music, manifested in the ability to understand, evaluate and adequately perceive works of musical art. The totality of its structural components (motivational-value, cognitive and evaluativereflexive components) characterizes the integral image of the phenomenon under study "[14, p. 202].

A special contribution to the formation and development of the theory and methodology of musical education was made by such prominent scientists, musicologists, composers, teachers as Academician B.V.Asafiev, O.A.Apraksina, L.A. Bezborodova, N.L. Grodzenskaya. D.B. Kabalevsky, Y.B. Aliev, and others [5, p. 336; 6, p. $224 ; 7$, p. $254 ; 8$, p. $200 ; 9$, p. $77 ; 10$, p. 224]. Their views are reflected in Table 1. 
Methods for the formation of students' musical comprehension in the theories of educational scientists

Table 1

\begin{tabular}{|c|l|}
\hline B.V. Asafiev & $\begin{array}{l}\text { Consideration of the formation of comprehension in the } \\
\text { context of intonation theory, analysis of musical material, } \\
\text { the role of performing activities at an accessible level }\end{array}$ \\
\hline V.N. Shatskaya & $\begin{array}{l}\text { The "constituent" components of musical comprehension: } \\
\text { musical experience aesthetic appreciation and the } \\
\text { development of the need for judgment. Repetition of } \\
\text { musical perceptions as a condition for personal assessment }\end{array}$ \\
\hline N.L. Grodzenskaya & $\begin{array}{l}\text { Comparison, juxtaposition in the perception of music, } \\
\text { activation of musical perception through vocalization } \\
\text { ("method of musical call signs") establishing the } \\
\text { relationship between perception and reproduction of music }\end{array}$ \\
\hline Y.B. Aliev & $\begin{array}{l}\text { The "sounding questionnaire" method - written answers } \\
\text { that allow you to get a certain idea of the level of } \\
\text { development of students' musical comprehensions }\end{array}$ \\
\hline L.A. Bezborodova & $\begin{array}{l}\text { The method of music interviews - conducting } \\
\text { conversations about music by a schoolchild among } \\
\text { classmates by }\end{array}$ \\
\hline D.B. Kabalevsky & $\begin{array}{l}\text { The thematic principle of building a music program, } \\
\text { reliance on life and musical experience (child's } \\
\text { impressions), the connection between music and life, active } \\
\text { analytical and creative perception of music, the method of } \\
\text { "running ahead" and "returning to the past" }\end{array}$ \\
\hline
\end{tabular}

Analysis of theoretical and musical pedagogical literature, as well as our pedagogical experience, allows us to state the following:

- the musical comprehension of a student of senior school age is based on musical and aesthetic experience;

- the ability to objectively and reasonably assess the active is assumed;

- successful participation in artistic and aesthetic activities in a music lesson.
We agree with the opinion of S.Sh. Umerkaeva that in the process of working on a piece of music, artistic comprehension is formed in one case, in the other it is improved, but the fact remains unchanged that students better understand the "laws of art" in practice, when they acquire skills and abilities associated with artistic embodiment and "imitation" of the beautiful - that is, in performance. The performer's comprehension, constantly involved in assessing the merits and demerits of creative 
work, is more active than when listening to music [15, pp. 1-7].

Individual performance in a generally accepted form, as a rule, is not present at a music lesson the exception is the performance of the teacher himself and individual children studying in music schools. The main type of collective performance is choral singing. Both that and another can be attributed to playing music, which makes it possible to intensively discover the possibility of interpretation and development of musical, creative, intellectual abilities of children.

Consequently, the specificity and at the same time the condition for the formation of the musical comprehension of students is:

- the need to create a stock and constant enrichment of aesthetic impressions and representations in visual-sensory and figurativeconceptual forms;

- organization of a gradual complication of musical material and an increase in the share of independence and initiative in the performing and evaluative activities of children;

- orientation towards the integrated development of art involves considering the issues of educating musical comprehension through the introduction of schoolchildren to various types of musical activity in their unity;

- providing cognitive and emotional richness of musical lessons due to the genre and stylistic diversity of musical material, combining samples of classical and modern musical art.

\section{Conclusion}

The formation of the musical comprehension of schoolchildren has great potential in the process of musical and aesthetic education of students for the following reasons.

It is able to educate:

- musical culture and musical comprehension among students of secondary schools (through musical and auditory perception) on the example of piano, vocal, opera and ballet works;

- a sense of patriotism, since the theme of the Motherland passes through all the composer's work;

- a feeling of love for nature, a special place in the composer's work is occupied by the images of nature, captured in the piano cycle "The Seasons".

Thus, the practical implementation of the system of pedagogical influences, built on the complex development of cognitive, perceptual, evaluative, performing components of musical classes and students' abilities, has a significant potential for the formation of the musical comprehension of schoolchildren.

\section{ReFERENCES}

1. Resolution of the President of the Republic of Uzbekistan "On measures to raise the system of spiritual, moral and physically harmonious education of young people, their training and education to a qualitatively new level" dated August 14, 2018 No. PD-3907. (Постановление Президента Республики Узбекистан «0 мерах по поднятию на качественно новый уровень системы духовнонравственного и физически гармоничного воспитания молодежи, ее обучения и воспитания» от 14 августа 2018 г. № ПП-3907.)

2. Resolution of the President of the Republic of Uzbekistan "On the organization of the activities of the Union of Composers and Compositions of Uzbekistan" No. PP-3212 dated 15.08.2017. (Постановление Президента Республики Узбекистан “Об организации деятельности Союза композиторов и бастакоров Узбекистана" 
CURRENT RESEARCH JOURNAL OF PEDAGOGICS 2(5): 78-83, May 2021

DOI: https://doi.org/10.37547/pedagogics-crjp-02-05-15

ISSN 2767-3278

(C)2021 Master Journals

Crossref doi 81 Google

Accepted 25th May, 2021 \& Published 31 th May, 2021

№ ПП-3212 от 15.08.2017.)

3. Adorno, T.V. (1998) Favorites: Sociology of Music. - Moscow; SPb: University book. (Адорно, Т.В. Избранное: Социология музыки. - М.; СПб: Университетская книга, 1998.)

4. Abdullin, E. B. (2004) Theory of music education: a tutorial for students. higher pedagogical institutions / E. B. Abdullin, E. V. Nikolaeva. - Moscow: Academy. - p 336. (Абдуллин, Э. Б. Теория музыкального образования : учеб. для студ. высш. пед. учеб. заведений / Э. Б. Абдуллин, Е. В. Николаева. - М.: Академия, 2004. - 336 c.)

5. Aliev Yu. B. (2000) Handbook of a school musician teacher. - Moscow: VLADOS. - p. 6: (Алиев Ю. Б. Настольная книга школьного учителя-музыканта. М.: ВЛАДОС, 2000. - 336 с.:)

6. Apraksina, O. A. (1983) Methods of musical education at school: a textbook for students of the pedagogical institute on special. № 2119 "Music and Singing". - Moscow: Education. - p. 224, (Апраксина, 0. А. Методика музыкального воспитания в школе : учеб. пособие для студ. пед. интов по спец. № 2119 «Музыка и пение». М.: Просвещение, 1983. - 224 с.

7. Bezborodova L.A. (2013) Theory and methodology of music education. Study guide for students. - Moscow: Flinta. - p. 254. (Безбородова Л.А. Теория и методика музыкального образования. Учебное пособие для студентов. - М.: Флинта, 2013. - 254 с.)

8. Shatskaya V.N. (1975) Musical and aesthetic education of children and youth. - Moscow: Education. - p. 200. (Шацкая B.H. Музыкально-эстетическое воспитание детей и юношества. - М.: Просвещение,
1975. - 200 c.)

9. Grodzenskaya N.L. (1969) Schoolchildren listen to music. - Moscow: Education. - p. 77. (Гродзенская Н.Л. Школьники слушают музыку. М.: Просвещение,1969.77 c.)

10. Kabalevsky D. (2005) How to tell children about music? - Moscow: Education. - p. 224. (Кабалевский Д. Как рассказывать детям о музыке? М.: Просвещение, 2005. - 224 c.)

11. Nurmatov H., Narkhodzhaev N. (2010) Music. Textbook for the 1st grade of secondary schools. - Tashkent: Publishing house named after G. Gulyama. - p. 88. (Нурматов Х., Нарходжаев Н. Музыка. Учебник для 1 класса общеобразовательных школ. Т.: Изд-во им. Г.Гуляма, 2010. - 88 с.)

12. Ibragimov 0. (2005) Music. Textbook for grade 4 of secondary schools. - Tashkent: publishing house named after G. Gulyama. p. 78. (Ибрагимов О. Музыка. Учебник для 4 класса общеобразовательных школ. Т.: изд-во им. Г. Гуляма, 2005. - 78 с.)

13. Strikhar O.I. Formation of musical-aesthetic comprehension and outlook of students based on the application of the principle of integration in music lessons // Young Scientist. - 2014. - No. 11. - pp. 423-425. URL https://moluch.ru/archive/70/12086/ (date of access: 16.01.2020). (Стрихар 0. И. Формирование музыкальноэстетического вкуса и кругозора учащихся на основе применения принципа интеграции на уроках музыки // Молодой ученый. - 2014. — №11. - C. 423-425. - - URL https://moluch.ru/archive/70/12086/ (дата обращения: 16.01.2020).)

14. Efremova, I. V. (2015) Pedagogical 
CURRENT RESEARCH JOURNAL OF PEDAGOGICS 2(5): 78-83, May 2021

DOI: https://doi.org/10.37547/pedagogics-crjp-02-05-15

ISSN 2767-3278

(C)2021 Master Journals

crossref do) 801 Google

Accepted 25 ${ }^{\text {th }}$ May, 2021 \& Published 31 ${ }^{\text {th }}$ May, 2021

conditions for the formation of musical comprehension among students in grades 56 of a comprehensive school. Diss. ... Candidate of pedagogical sciences. Yelets. p. 202. (Ефремова, И. В. Педагогические условия формирования музыкального вкуса у учащихся 5 - 6 классов общеобразовательной школы. Дисс. ... канд. пед. наук. Елец, 2015. - 202 с.)

15. Umerkaeva S. Sh. (2015) Education of artistic comprehension as a musical and pedagogical problem Concept. - pp. 1-7. (Умеркаева С. Ш. Воспитание художественного вкуса как музыкальнопедагогическая проблема Концепт, 2015. - C.1-7.)

16. Udalova R.I. (2016) Pedagogical technology of forming the foundations of the musical comprehension of younger schoolchildren in extracurricular activities: Diss. ... Candidate of pedagogical sciences: - Moscow: - p. 278. (Удалова Р. И. Педагогическая технология формирования основ музыкального вкуса младших школьников во внеурочной деятельности: Дисс. ... канд. пед. наук: Москва, 2016.- 278 с.) 